\title{
RESOLUTION OF THE HIRAEA CEPHALOTES COMPLEX (MALPIGHIACEAE)
}

\author{
C. E. ANDERSON
}

\begin{abstract}
The assemblage of specimens from Brazil, Colombia, Ecuador, Peru and western Venezuela that had been determined as a variable species, Hiraea cephalotes Triana \& Planch. (Malpighiaceae), was found to comprise seven species in addition to $H$. cephalotes (Colombia, Ecuador). Six are newly described: Hiraea amazonica C.E.Anderson (Brazil), H. angustipetala C.E.Anderson (Ecuador), H. breteleri C.E.Anderson (Venezuela), H. ecuadorensis C.E.Anderson (Ecuador), H. escobariae C.E.Anderson (Colombia), and $H$. peruviana C.E.Anderson (Peru). Hiraea spruceana var. mortoniana J.F.Macbr. is elevated to the rank of species as H. mortoniana (J.F.Macbr.) C.E.Anderson (Peru). The name Hiraea spruceana Nied. is confirmed as a synonym of $H$. cephalotes. All eight species are characterised by having the flowers borne in axillary, multiflowered umbels. All but one have styles with a blunt apex; in Hiraea amazonica the apex of the styles is drawn out into a short spur. All species are illustrated.
\end{abstract}

Keywords. Brazil, Colombia, Ecuador, Hiraea, Malpighiaceae, Peru, Venezuela.

\section{INTR ODUCTION}

Hiraea Jacq. (Malpighiaceae) includes c.60 species of woody vines or shrubs ranging from southern Mexico to Argentina. The genus is characterised by stipules inserted on the petiole, bilaterally symmetrical flowers in umbellate axillary inflorescences, and butterfly-shaped samaras. The flowers are borne in two kinds of aggregates, either in umbels of 4(-6), singly or in secondary arrangements, or in multiflowered umbels on an inflorescence axis; all the species described here fall into the latter category. Only two authors have treated the genus as a whole, Jussieu (1843) and Niedenzu $(1906,1912,1928)$, but both saw very few collections from western South America. The most recent detailed account of Hiraea in that region is that of Cuatrecasas (1958) in his treatment of the Malpighiaceae for his 'Flora Colombiana' project.

In the absence of modern assessments of Hiraea in South America, the names $H$. cephalotes and $H$. spruceana have been loosely applied to specimens with multiflowered umbels and pubescent leaves from Colombia, Ecuador and Peru, and also western Venezuela and even central Brazil. Study of collections so determined showed that they include eight species, Hiraea cephalotes (including H. spruceana), H. mortoniana (elevated to rank of species from variety of $H$. spruceana), and six novelties: $H$. amazonica, $H$. angustipetala, $H$. breteleri, $H$. ecuadorensis, $H$. escobariae and $H$. peruviana. 
Hiraea cephalotes was described by Triana \& Planchon (1862) from a Triana collection obtained in southern Colombia. Niedenzu $(1906,1928)$ did not see the type of Hiraea cephalotes and thought the name a synonym of Hiraea multiradiata A.Juss.; he (1912) based H. spruceana on a collection from Ecuador. Sprague (1924) pointed out that Hiraea multiradiata, based on Banisteria quarapa Aubl. from French Guiana, is a superfluous name and proposed the combination in Hiraea. He also noted that Hiraea cephalotes applies to a species different from $H$. quarapa (Aubl.) Sprague, and that $H$. spruceana is a synonym for $H$. cephalotes. To these names, Macbride (1950) added Hiraea spruceana var. mortoniana in his account of Hiraea for his 'Flora of Peru', although with uncertainty about this taxon's affinities.

Cuatrecasas (1958) recognised in Colombia two species with multiflowered umbels in which the styles have a blunt apex; in the majority of species, the styles are dorsally extended into a spur or hook. One is Hiraea ferruginea Cuatrec., distinctive in its ternate leaves, short and stout petioles (3-4.5 mm wide) with large stipules (to $1 \mathrm{~cm}$ long), and umbels containing (45-)50-60(-65) flowers. The other is Hiraea cephalotes, which has opposite leaves with petioles half as thick, stipules to $2 \mathrm{~mm}$ long, and umbels with 11-23 flowers. The limb of the lateral petals is subentire, but that of the posterior petal is digitate-fimbriate. An unusual aspect of this species, not noted by previous authors, is the sericeous vesture on the adaxial surface of the sepals, a trait shared only with Hiraea angustipetala among the species discussed here. The species here newly described, except for Hiraea amazonica, have blunt styles. In most species of Hiraea the stigma is placed at the internal angle of the apex, i.e. toward the centre of the flower, but in $H$. angustipetala and $H$. breteleri the stigma is terminal.

Many species of Hiraea are surprisingly variable in leaf shape, even in different parts of the same plant. Also, leaf vesture can be bewilderingly different in young and old leaves. Young laminas may be abundantly pubescent; older laminas are often glabrescent to glabrous adaxially; the abaxial vesture may thin greatly and/or slough off in patches or entirely. The descriptions presented here, except for that of Hiraea cephalotes, are based on one or few collections, and may well be amended as additional material becomes available.

\section{SPECIES DESCRIPTIONS}

\section{Hiraea amazonica C.E.Anderson, sp. nov. Fig. 1.}

A Hiraea cephalote foliis margine eglanduloso, sepalis adaxaliter glabris et stylis breviter uncinatis differt. - Type: Brazil, Amazonas, Mpio. Itapiranga, lado esquerdo do igarapé Catitu, atrás de antiga Usina de Pau-Rosa, 20 viii 1979 (fl), C.A. Cid et al. 546 (holo MICH; iso INPA excluding leafy branch, MG, NY).

Woody vine. Leaves opposite; petioles $0.7-1 \mathrm{~cm}$ long, $2.5-3 \mathrm{~mm}$ wide, densely covered with T-shaped hairs; stipules 2.5-3 mm long, borne in the middle to basal 1/4 of petiole; laminas of the larger leaves $9-17 \times 5.2-13.5 \mathrm{~cm}$, narrowly to broadly elliptical to suborbicular, apex apiculate to briefly acuminate, base rounded to cordate, adaxially 


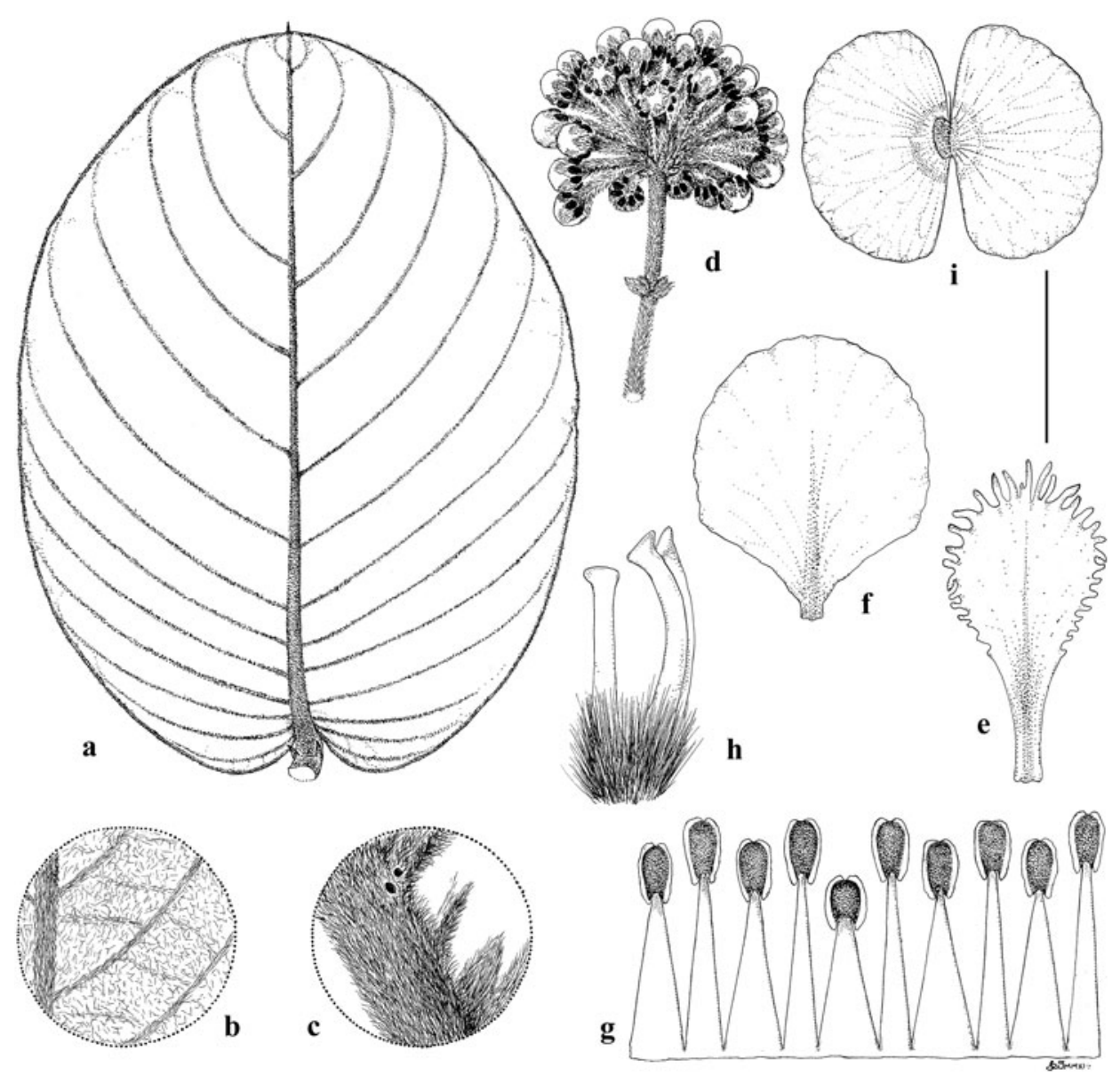

FIg. 1. Hiraea amazonica C.E.Anderson. a, large leaf, adaxial view; $b$, detail of abaxial leaf surface; c, petiole and lamina base, abaxial view, showing a pair of stipules and two glands at base of lamina; $d$, inflorescence in bud; e, posterior petal; f, lateral petal; g, androecium laid out, abaxial view, the stamen fifth from left opposite posterior petal; h, gynoecium, anterior style at left; i, samara, abaxial view, showing dorsal wing. Scale bar equivalents: a, $4 \mathrm{~cm} ; \mathrm{b}, 1.3 \mathrm{~cm}$; c, 8 mm; d, 2 cm; e, f, 4 mm; g, h, 2.7 mm; i, 2 cm. Based on: a-c, Anderson 13770 (MICH); d-h, Cid et al. 546 (MICH); i, Mota \& Mota 226 (INPA).

with $\mathrm{T}$ - and $\mathrm{Y}$-shaped hairs when young to glabrate but the vesture retained on the costa and secondary veins, abaxially densely pubescent with T-shaped hairs (sparser with age), the hairs with a stalk $0.1-0.3(-0.5) \mathrm{mm}$ long, the trabecula $0.2-1.2 \mathrm{~mm}$ long, wavy; adaxially costa and secondary veins impressed; abaxially costa, secondary and tertiary veins prominent; leaf glands: marginal glands absent; lamina abaxially with a pair of glands borne near or at the base, sometimes with additional smaller glands, each gland c. $0.5 \mathrm{~mm}$ long, and/or sometimes with 1 or 2 glands at the apex of the petiole, each gland $0.5-1 \mathrm{~mm}$ long. Inflorescence a solitary 15-25(-30)-flowered 
umbel borne on an axis $2-4.5 \mathrm{~cm}$ long, with a node bearing deciduous leafy bracts in the middle to distal 1/4; umbel without a gland in the centre; bracts $0.7-1.2 \times 0.4-0.5 \mathrm{~mm}$, bracteoles like bracts or slightly shorter and/or narrower; pedicels $10-15 \times 0.8-1 \mathrm{~mm}$; axes, abaxial surface of bracts and bracteoles, and pedicels densely pubescent with subsessile T-shaped hairs. Sepals 2.5-2.8 × 2-2.4 mm, triangular, adaxially glabrous, abaxially densely sericeous; anterior sepal eglandular or rarely with 1 gland c. $0.5 \mathrm{~mm}$ long, the lateral four biglandular, glands 1.5-2 mm long. Petals yellow to orange, glabrous; lateral petals with the free portion of the claw c. $1 \mathrm{~mm}$ long, limb of anteriorlateral petal c. $6 \times 6 \mathrm{~mm}$, limb of posterior-lateral petal c. $5 \times 5 \mathrm{~mm}$, both orbicular and strongly decurrent, margin subentire to denticulate; posterior petal with the claw 2.5-3 mm long and thicker than that of lateral petals, limb 5-5.5 × c.4 mm, elliptical, margin fimbriate, fimbriae to $1 \mathrm{~mm}$ long at apex, decreasing in size toward base. Stamens glabrous, filaments basally connate; stamen opposite anterior sepal: filament 2.5-2.7 mm long, anther c. $1.5 \mathrm{~mm}$ long; stamens opposite lateral petals: filaments c. $2.2 \mathrm{~mm}$ long, anthers c. $1 \mathrm{~mm}$ long; stamens opposite lateral sepals: filaments $2.5-2.7 \mathrm{~mm}$ long, anthers c. $1.3 \mathrm{~mm}$ long; stamen opposite posterior petal: filament c. $2 \mathrm{~mm}$ long, anther c. $1 \mathrm{~mm}$ long. Styles glabrous, stigma on the internal angle of the apex; anterior style c. $2.5 \times$ c. $0.3 \mathrm{~mm}$, erect, apex extended into a spur c. $0.05 \mathrm{~mm}$ long; posterior styles c. $3 \times$ c. $0.3 \mathrm{~mm}$, incurved, apex extended into a spur to $0.1 \mathrm{~mm}$ long; ovary 1.5-1.6 mm long, densely villous. Samara butterfly-shaped; lateral wings c. $3 \times$ c. $1.7 \mathrm{~cm}$, dorsal wing c. $3 \mathrm{~mm}$ high; nut spherical, $5-6 \mathrm{~mm}$ in diameter, areole c. $2-3 \mathrm{~mm}$ in diameter; mature seed not seen.

\section{Distribution. Brazil (Amazonas).}

Habitat. Lowland forest on terra firma, capoeira.

Additional specimens examined. BrAzIL. Amazonas: Manaus, SUFRAMA Industrial District, capoeira just N of new Hospital Adventista, 14 ii 1990 (sterile), Anderson 13770 (MICH); estrada Manaus-Itacoatiara, Km 8, Rosa de Maio, 2 xii 1975 (fr), Mota \& Mota 226 (INPA).

Hiraea amazonica differs from all the other species described here in its styles, which have the apex extended into a short spur (Fig. 1h); the anterior style is erect, but the longer posterior two are incurved. Also, the limb of the petals is strongly decurrent, especially that of the lateral petals. Only the type collection includes some open flowers; this gathering includes branches with a few leaves and many umbels, but mostly only in bud. The duplicate at INPA consists of two branchlets with umbels in bud as well as a leafy branch from another plant that does not belong to Malpighiaceae.

\section{Hiraea angustipetala C.E.Anderson, sp. nov. Fig. 2.}

A Hiraea cephalote stipulis brevioribus, petalis angustis, et stylis stigmate terminali differt. - Type: Ecuador, Zamora-Chinchipe, area of ECF (Estación Científica San Francisco) Research Station, c.30 km away from city of Loja on hwy towards

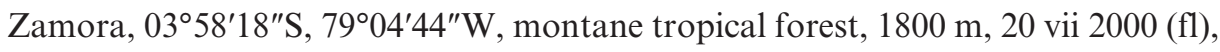
Matezki 304 (holo $\mathrm{MICH}$; iso $\mathrm{MICH}$ ). 


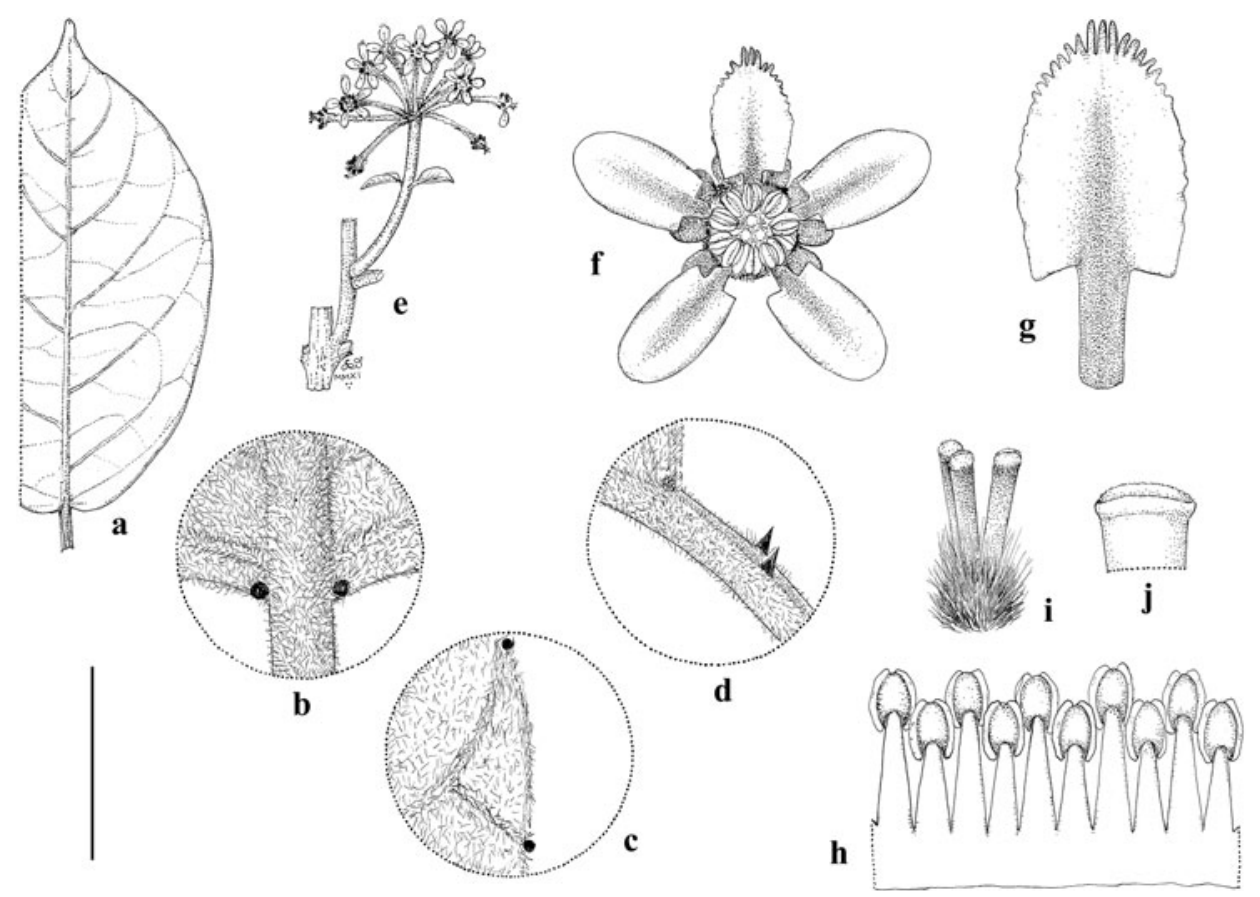

Fig. 2. Hiraea angustipetala C.E.Anderson. a, large leaf, abaxial view; b, detail of leaf base, abaxial view, showing two basal glands; c, detail of abaxial leaf surface, showing pubescence and marginal glands; d, distal portion of petiole with a pair of stipules and base of lamina; e, flowering branch; f, flower; g, posterior petal; h, androecium laid out, abaxial view, the stamen second from left opposite posterior petal; i, gynoecium, anterior style at right; $\mathrm{j}$, detail of apex of style, showing terminal stigma. Scale bar equivalents: $\mathrm{a}, 4 \mathrm{~cm} ; \mathrm{b}-\mathrm{d}$, $4 \mathrm{~mm}$; e, $4 \mathrm{~cm}$; f, $5 \mathrm{~mm}$; g-i, $2.7 \mathrm{~mm}$; j, $1 \mathrm{~mm}$. Based on: a-d, Matezki 431 (MICH); e-j, Ellemann 75373 (AAU).

Woody vine to $6 \mathrm{~m}$. Leaves opposite; petioles $0.7-1 \mathrm{~cm}$ long, c. $2 \mathrm{~mm}$ wide, densely covered with Y-and T-shaped hairs; stipules $0.3-1 \mathrm{~mm}$ long, borne in the middle or distal 1/4 of petiole, caducous; laminas of the larger leaves $3.7-10 \times 2-6 \mathrm{~cm}$, elliptical to narrowly ovate, apex mucronate to acuminate, base truncate or rounded, adaxially velutinous, the hairs Y-shaped, with a stalk $0.05-0.1 \mathrm{~mm}$ long, the arms mostly unequal, rudimentary to $0.3 \mathrm{~mm}$ long, abaxially with a mixture of $\mathrm{Y}$ - and T-shaped hairs, the T-shaped hairs with a stalk $0.05-0.15 \mathrm{~mm}$ long, the trabecula $0.3-0.5 \mathrm{~mm}$ long, wavy or crisped; adaxially veins not impressed; abaxially costa, secondary and tertiary veins prominent; leaf glands: margin with scattered glands $0.1-0.2 \mathrm{~mm}$ in diameter, sometimes only in distal $1 / 5$ or absent; a pair of glands borne abaxially at the base of the lamina or at the apex of the petiole, each gland $0.3-0.4 \mathrm{~mm}$ long, or glands absent. Inflorescence a solitary 12-14-flowered umbel borne on an axis 1-3.7 cm long, at the middle or distal 1/3-1/4 or immediately below the umbel with a node bearing a pair of leafy bracts or reduced leaves (petiole to $0.2 \mathrm{~mm}$ long, lamina to $11 \mathrm{~mm}$ long, to $7 \mathrm{~mm}$ 
wide); umbel without a gland in the centre; bracts $0.7-1 \times 0.4-0.6 \mathrm{~mm}$, bracteoles like bracts or slightly shorter and/or narrower, all abaxially densely sericeous; pedicels 9-17 × 0.8-1 mm, axes and pedicels densely covered by T-shaped hairs. Sepals 1.5-1.7 × 1.5-1.7 mm, triangular, adaxially sericeous, abaxially densely sericeous; anterior sepal eglandular, the lateral four biglandular, glands $1.8-2 \mathrm{~mm}$ long, prominent. Petals yellow to orange, tinged with red, glabrous; lateral petals with the claw $1.2-1.4 \mathrm{~mm}$ long, limb 3.3-3.6 $\times 2.5-3 \mathrm{~mm}$, elliptical, margin entire or subentire; posterior petal with the claw 1.3-1.6 mm long and thicker than that of lateral petals, limb 3.5-3.9 $\times$ 2.6-2.7 mm, elliptical, margin subentire but the apex digitate-fimbriate, the fimbriae to $0.5 \mathrm{~mm}$ long. Stamens glabrous, filaments basally connate; stamen opposite anterior sepal: filament $2.2-2.5 \mathrm{~mm}$ long, anther c. $1 \mathrm{~mm}$ long; stamens opposite lateral petals: filaments $1.8-2 \mathrm{~mm}$ long, anthers $0.7-0.9 \mathrm{~mm}$ long; stamens opposite lateral sepals: filaments 2-2.4 mm long, anthers c. $1 \mathrm{~mm}$ long; stamen opposite posterior petal: filament 1.5-2 mm long, anther 0.8-0.9 mm long. Styles glabrous, erect, apex blunt, stigma terminal; anterior style $1.5-1.7 \times$ c. $0.3 \mathrm{~mm}$; posterior styles $1.7-1.9 \times$ c. $0.3 \mathrm{~mm}$; ovary c. $1 \mathrm{~mm}$ long, densely villous. Mature samara not seen; immature samaras butterfly-shaped, dorsal wing present.

Distribution. Ecuador (Loja, Zamora-Chinchipe).

Habitat. Montane tropical rain forest; 1800-2600 m.

Additional specimens examined. ECUADOR. Loja: Loja-Zamora, $12 \mathrm{~km}$ from Loja, on the finca

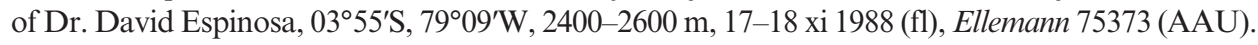
Zamora-Chinchipe: area of Finca San Ramón de Yanacocha, Km 11 on hwy Loja-Zamora, $03^{\circ} 59.275^{\prime} \mathrm{S}, 79^{\circ} 09.461^{\prime} \mathrm{W}, 2400 \mathrm{~m}, 28$ x 2001 (fl, y fr), Matezki $431(\mathrm{MICH})$.

Hiraea angustipetala shares with $H$. cephalotes adaxially sericeous sepals, but differs in its smaller flowers with narrow petals, of which the posterior limb bears only a few fimbriae at the apex, and styles with a terminal stigma. The laminas are velutinous, and the stipules are only up to $1 \mathrm{~mm}$ long and apparently caducous. The immature fruits of Matezki 431 show that the samaras have a short dorsal wing.

\section{Hiraea breteleri C.E.Anderson, sp. nov. Fig. 3.}

A Hiraea cephalote umbellis 8-10-floris, sepalis adaxaliter glabris et stylis stigmate terminali differt. - Type: Venezuela, Táchira, Mpio. Libertad, lugar Copa de Sombre, camino Capacho-Cerro Cristo Rey, 1645 m, 18 ix 1998 (fl), Stergios et al. 18033 (MICH).

Woody vine. Leaves opposite; petioles $0.7-1.5 \mathrm{~cm}$ long, $1.2-2 \mathrm{~mm}$ wide, densely sericeous; stipules 1.5-2 mm long, borne in the middle to basal 1/4 of petiole; laminas of the larger leaves $5.5-18 \times 3-8 \mathrm{~cm}$, lanceolate or narrowly to broadly elliptical to narrowly obovate, apex apiculate to acuminate to long-acuminate (acumen to $2 \mathrm{~cm}$ in largest leaves), base acute to rounded or truncate, adaxially with T- and Y-shaped hairs but soon glabrescent to glabrous or the vesture retained on the costa toward the base, abaxially densely pubescent with T-shaped hairs (becoming sparser with age), 


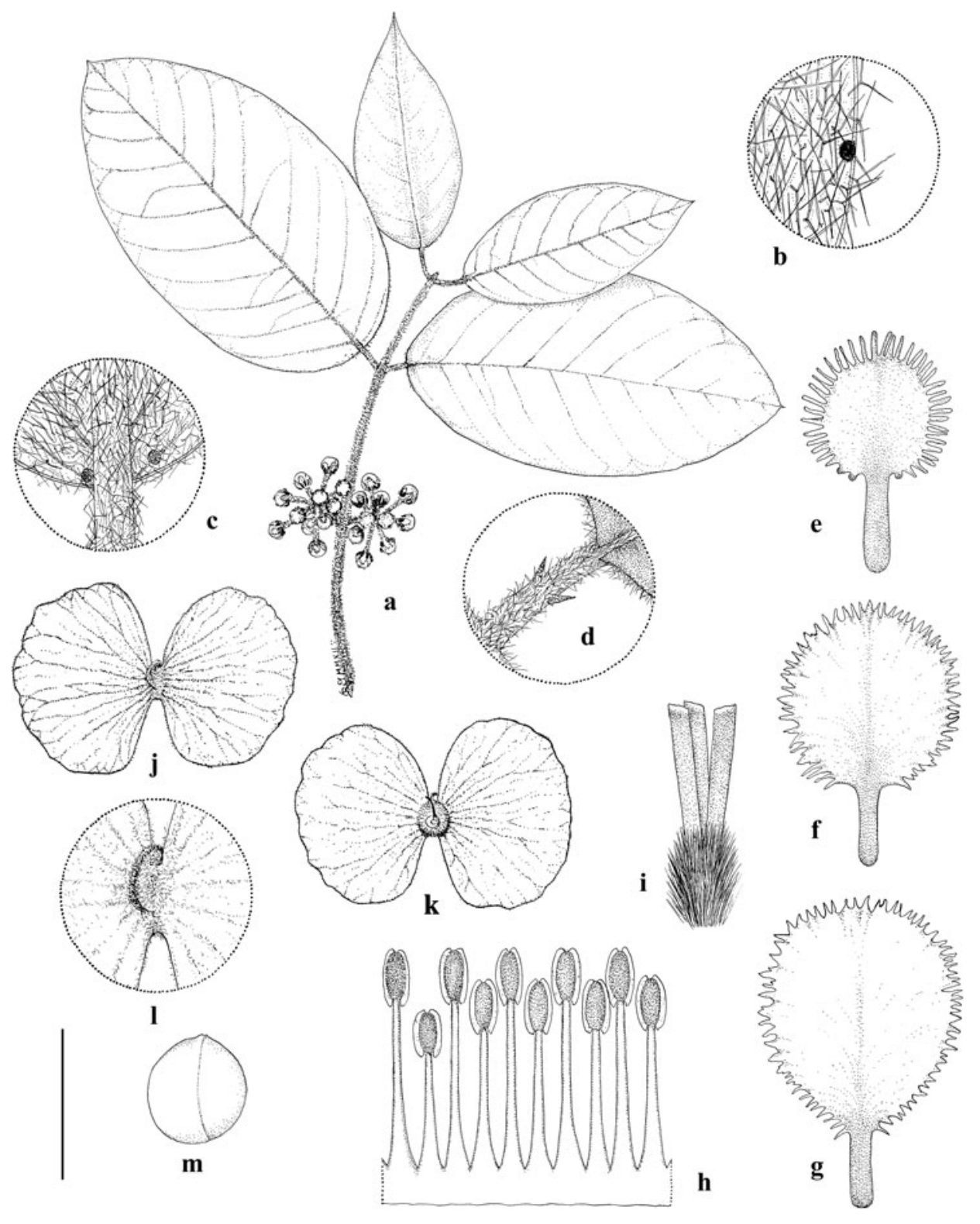

Fig. 3. Hiraea breteleri C.E.Anderson. a, flowering branch; b, detail of lamina, abaxial view, showing marginal gland; c, base of lamina with a pair of glands, abaxial view; d, base of lamina, adaxial view, and petiole with a pair of stipules; e, posterior petal; f, posterior-lateral petal; $\mathrm{g}$, anterior-lateral petal; $\mathrm{h}$, androecium laid out, abaxial view, the stamen second from left opposite posterior petal; i, gynoecium, anterior style at right; j, samara, abaxial view; k, samara, adaxial view; 1, detail of samara, showing dorsal wing; $\mathrm{m}$, embryo. Scale bar equivalents: a, $4 \mathrm{~cm}$; b, $2.7 \mathrm{~mm}$; c, $4 \mathrm{~mm}$; d, $8 \mathrm{~mm}$; e-g, $4 \mathrm{~mm}$; h, $2.7 \mathrm{~mm}$; i, $2 \mathrm{~mm}$; j, k, $2.7 \mathrm{~cm} ; 1,1.3 \mathrm{~cm}$; m, 6.7 mm. Based on: a-i, Stergios et al. 18033 (MICH); j-m, Breteler 3414 (NY). 
the hairs with a stalk $0.1-0.3 \mathrm{~mm}$ long, the trabecula $0.4-1.3 \mathrm{~mm}$ long, wavy or crisped; adaxially veins not impressed; abaxially costa and secondary veins prominent and tertiary veins prominulous; leaf glands: margin (or only the distal 1/2) with scattered glands c. $0.2 \mathrm{~mm}$ in diameter; lamina abaxially with a pair of glands borne near or at the base or at the apex of the petiole, each gland $0.3-0.5 \mathrm{~mm}$ long, sometimes with only 1 gland, or glands absent. Inflorescence a solitary (8-)10-flowered umbel borne on an axis $0.5-1.7 \mathrm{~cm}$ long, with a node bearing deciduous leafy bracts immediately or up to $2 \mathrm{~mm}$ below the umbel; umbel without a gland in the centre; bracts $0.8-1 \times 0.5-0.6 \mathrm{~mm}$, bracteoles like bracts or slightly shorter and/or narrower; pedicels 11-13 × c. $1 \mathrm{~mm}$; axes, abaxial surface of bracts and bracteoles, and pedicels densely sericeous. Sepals $2.7-3 \times 1.5-1.7 \mathrm{~mm}$, narrowly triangular, adaxially glabrous, abaxially densely sericeous; anterior sepal eglandular, the lateral four biglandular, glands c. $1.5 \mathrm{~mm}$ long. Petals yellow to orange, glabrous; lateral petals with the claw c. $2 \mathrm{~mm}$ long, limb of anterior-lateral petal c. $6 \times 6 \mathrm{~mm}$, limb of posterior-lateral petal c. $5 \times 5 \mathrm{~mm}$, both orbicular, margin denticulate-fimbriate, the teeth-fimbriae to $0.4 \mathrm{~mm}$ long; posterior petal with the claw c. $2.5 \mathrm{~mm}$ long and thicker than that of lateral petals, limb 3.5-4 $\mathrm{mm}$ long and wide, orbicular, margin digitate-fimbriate, fimbriae to $0.6 \mathrm{~mm}$ long, at the base with a few short glands (c.0.1 mm long). Stamens glabrous, filaments basally connate; stamen opposite anterior sepal: filament c. $3 \mathrm{~mm}$ long, anther c. $1.2 \mathrm{~mm}$ long; stamens opposite lateral petals: filaments c. $2.5 \mathrm{~mm}$ long, anthers c. $1.2 \mathrm{~mm}$ long; stamens opposite lateral sepals: filaments c. $3 \mathrm{~mm}$ long, anthers c. $1.2 \mathrm{~mm}$ long; stamen opposite posterior petal: filament c. $2 \mathrm{~mm}$ long, anther c. $1 \mathrm{~mm}$ long. Styles glabrous, erect and very slightly divergent, apex blunt, stigma terminal; anterior style and posterior styles c. $2-2.3 \times$ c. $0.2 \mathrm{~mm}$; ovary c. $1.8 \mathrm{~mm}$ long, densely villous. Samara butterfly-shaped; lateral wings $3-3.5 \times 2.2-2.5 \mathrm{~cm}$, dorsal wing 2-3 $\mathrm{mm}$ high; nut spherical, 5-6 $\mathrm{mm}$ in diameter, areole c.2-3 $\mathrm{mm}$ in diameter; embryo spherical, outer cotyledon c. $4.5 \times$ c. $3.2 \mathrm{~mm}$, inner cotyledon c. $4 \times$ c. $3.2 \mathrm{~mm}$, cotyledons not folded.

Distribution. Venezuela (Táchira, Mérida).

Habitat. Primary forest on rocky slope, disturbed areas and roadsides; 1645-1750 m.

Etymology. The species is named for the eminent Dutch botanist Franciscus Jozef Breteler (b. 1932), who first collected it.

Additional specimens examined. Venezuela. Mérida: $35 \mathrm{~km}$ W of Mérida along road to La Carbonera, 1750 m, 3 xii 1963 (fr), Breteler 3414 (MER, NY, WAG).

Hiraea breteleri is distinctive in its 8-10-flowered umbels borne on very short peduncles (less than $2 \mathrm{~cm}$ long), denticulate-fimbriate lateral petals, and styles with a terminal stigma, which separate it from $H$. cephalotes.

Hiraea cephalotes Triana \& Planch., Ann. Sci. Nat. Bot., sér. 4, 18: 331 (1862). - Type: Colombia, Nariño, Pasto, [vi 1853, fide Dugand, 1944; fl, fr], Triana s.n. [5568] (holo P; iso BM, COL, K). Fig. 4. 


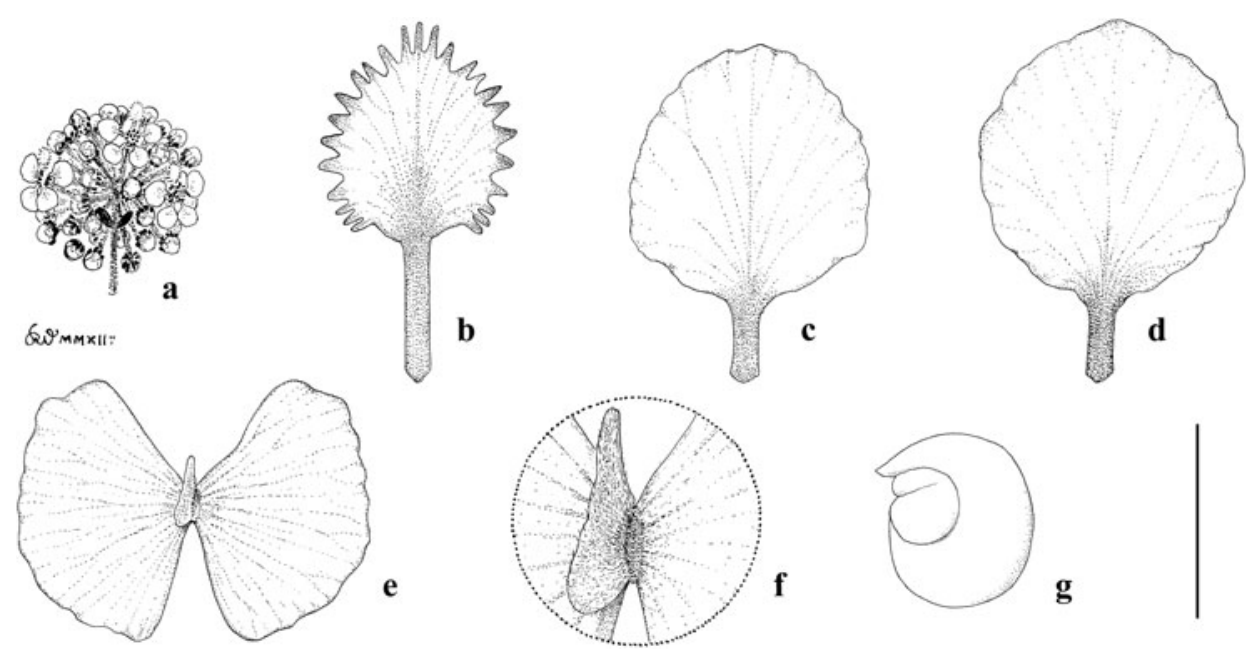

Fig. 4. Hiraea cephalotes Triana \& Planch. a, inflorescence; b, posterior petal; c, posteriorlateral petal; d, anterior-lateral petal; e, samara, abaxial view; $f$, detail showing dorsal wing of samara; g, embryo. Scale bar equivalents: a, 4 cm; b-d, 4 mm; e, $2.7 \mathrm{~cm}$; f, $1 \mathrm{~cm} ; \mathrm{g}, 8 \mathrm{~mm}$. Based on: a, Toro 923 (NY); b-d, Barkley 18C655 (US); e-g, Clark 190 (MICH).

Hiraea spruceana Nied., Arbeiten Bot. Inst. Königl. Lyceum Hosianum Braunsberg 4: 7 (1912). - Type: Ecuador, ad pedem m. Chimborazo, 3000 ft, viii 1860 (fl), Spruce 6152 (holo $\mathrm{B} \dagger$, photo $\mathrm{F}$; iso $\mathrm{BM}, \mathrm{CGE}, \mathrm{K}$ ).

Woody vine. Leaves opposite; petioles $0.8-3 \mathrm{~cm}$ long, 2-3 mm wide, densely tomentose, the hairs matted; stipules 1.5-2 mm long, borne in the basal 1/4 of petiole; laminas of the larger leaves $9-26 \times(4.5-) 5.5-16 \mathrm{~cm}$, narrowly to broadly elliptical to obovate, apex apiculate or acuminate, base truncate or briefly acute, adaxially with T-shaped hairs when young, becoming glabrate to glabrous, abaxially with T-shaped hairs, the hairs with a stalk $0.1-0.5 \mathrm{~mm}$ long, the trabecula $0.5-1(-1.4) \mathrm{mm}$ long, the arms often unequal, straight or crisped; adaxially costa and secondary veins not impressed; abaxially costa, secondary and tertiary veins prominent; leaf glands: margin with scattered glands $0.1-0.6 \mathrm{~mm}$ in diameter; lamina abaxially with a pair of glands borne at the base, each gland $0.2-1.5 \mathrm{~mm}$ long, or glands absent; petiole usually with $1-2$ glands at apex or up to $2 \mathrm{~mm}$ below apex, each gland $0.5-1.5 \mathrm{~mm}$ long. Inflorescence a solitary 11-23-flowered umbel borne on an axis $1.5-5 \mathrm{~cm}$ long, with a node bearing a pair of leafy bracts or reduced leaves (petiole to $2 \mathrm{~mm}$ long, lamina to $12 \mathrm{~mm}$ long, to $8 \mathrm{~mm}$ wide, elliptical to orbicular) immediately below the umbel or at the middle to distal $1 / 4$; umbel without a gland in the centre; bracts $0.7-1 \times 0.7-1 \mathrm{~mm}$, bracteoles like bracts or slightly shorter and/or narrower; pedicels $8-14 \times 1-2 \mathrm{~mm}$; axes, abaxial surface of bracts and bracteoles, and pedicels densely covered by subsessile T-shaped hairs. Sepals $1.3-2.8 \times 1.8-2.5 \mathrm{~mm}$, narrowly triangular, adaxially and abaxially densely sericeous; anterior sepal eglandular, the lateral four biglandular, glands $1.5-2.5 \mathrm{~mm}$ 
long. Petals yellow, glabrous; lateral petals with the claw 1.5-2 mm long, limb (3.5-)4-5 $\times$ 4-5 mm, orbicular, margin subentire; posterior petal with the claw 2-2.7 $\mathrm{mm}$ long and thicker than that of lateral petals, limb 3.5-4.5 $\times 3.5-4.5 \mathrm{~mm}$, broadly obovate to suborbicular, margin glandular-fimbriate or only in the distal $1 / 2-3 / 4$, fimbriae to $0.5(-0.8) \mathrm{mm}$ long, those at the apex commonly the longest. Stamens glabrous, filaments basally connate; stamen opposite anterior sepal: filament $2.5-3 \mathrm{~mm}$ long, anther 1.2-1.4 mm long; stamens opposite anterior-lateral petals: filaments $2.3-2.5 \mathrm{~mm}$ long, anthers c. $1.2 \mathrm{~mm}$ long; stamens opposite anterior-lateral sepals: filaments $2.5-3 \mathrm{~mm}$ long, anthers 1.2-1.3 mm long; stamens opposite posterior-lateral petals: filaments 1.5-2.5 mm long, anthers c. $1.2 \mathrm{~mm}$ long; stamens opposite posterior-lateral sepals: filaments 2.2-2.5 mm long, anthers c.1.2 mm long; stamen opposite posterior petal: filament 1.7-2 mm long, anther c.1.2 mm long. Styles glabrous, erect or very slightly divergent, apex blunt, stigma on the internal angle of the apex; anterior style 1.5-2 $\times$ $0.3 \mathrm{~mm}$; posterior styles $2-3 \times 0.2-0.3 \mathrm{~mm}$; ovary c. $2 \mathrm{~mm}$ long, densely villous. Samara butterfly-shaped; lateral wings 3.5-4 × 2.2-2.6 cm, dorsal wing $1.5-2 \mathrm{~mm}$ high, with a tooth to $5 \mathrm{~mm}$ long at the apex of the nut; nut subspherical, $5-6 \mathrm{~mm}$ in diameter, areole $1-1.5 \mathrm{~mm}$ in diameter, circular; embryo subspherical, $4.3-4.5 \mathrm{~mm}$ in diameter, outer cotyledon c. $7 \mathrm{~mm}$ long, folded at c. $1 / 2$ over the inner cotyledon, inner cotyledon c. $2.5 \mathrm{~mm}$ long, folded at c. $1 / 2$.

Distribution. Colombia (Antioquia, Cauca, Cesar, Huila, Nariño, Valle), Ecuador (Bolívar, Esmeraldas, Los Ríos).

Habitat. In premontane and tropical wet forest, at roadsides, along river banks; 150 $1800 \mathrm{~m}$.

Additional specimens examined. Colombia. Antioquia: alrededores de Antioquia, 1000 m, 20 iv 1948 (fl), Barkley 18C655 (US); Mpio. Urrao, Vereda Calles, Río Calles, Parque Nacional

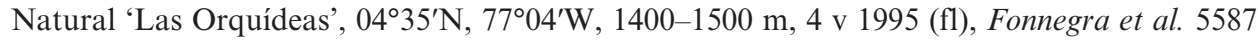
(MICH); vicinity of Medellín, 22 i 1928 (fl), Toro 923 (NY). Cauca: around Tacueyó, Río Palo Valley, Huila group, central Cordillera, 1800 m, i 1906 (fr), Pittier 1483 (US). Cesar: ['Magdalena'] Sierra de Perijá, east of Manaure, Hacienda Nuevo Horizonte, El Podrido, 16 xi 1959 (fl), Cuatrecasas \& Castañeda 25397 (US). Huila: Cordillera Oriental, E of Neiva, 1300 1800 m, 1-8 viii 1917 (fr), Rusby \& Pennell 940 (NY). Valle: Cordillera Occidental, vertiente oriental, hoya del Río Cali, vertiente derecha confluencia del Río Pichindecito con el Pichindé, 1580-1650 m, 7 xi 1944 (fl), Cuatrecasas 18775 (COL, F, US); Cordillera Occidental, La Cumbre, entre residuos de monte, 1680 m, 24 ii 1945 (fl, fr), Cuatrecasas 19554 (F, US); Cordillera

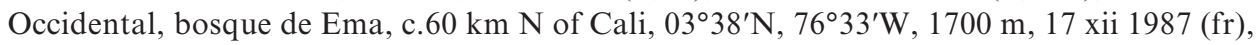
Gentry et al. 59532 (MICH, MO); Cali, La Buitrera, margen del Río Lili, 1200 m, 11 i 1986 (fr), González 25 (MICH); Cordillera Central, vertiente occidental, alrededores de La Buitrera, Palmira, 27 ix 1962 (fl), López Figueiras 8004 (US); Cordillera Occidental, Espinal, 1000 m, 27 vi 1945 (fr), von Sneidern 4420 (F, US).

EcuAdor. Bolívar: Atio de Telimbela, descenco de Cord. Occidental, 1500 m, 18 xi 1943 (fr), Acosta Solís 6902 (F). Esmeraldas: Quinindé, Bilsa Biological Station, Mache Mtns, 35 km W of Quinindé, $5 \mathrm{~km} \mathrm{~W}$ of Santa Isabel, $00^{\circ} 21^{\prime} \mathrm{N}, 7^{\circ} 44^{\prime} \mathrm{W}, 400-600 \mathrm{~m}, 14$ x 1994 (fr), Clark 190 (MICH, MO, NY, US). Los Ríos: Río Palenque Biological Station, Km 56, Quevedo-Santo Domingo, 150-220 m, 26 x 1974 (fl), Dodson 5647 (SEL, US); on property 
of Manuel Bravo, $4 \mathrm{~km}$ W of Los Angeles, Km 51, Quevedo-Santo Domingo road, $200 \mathrm{~m}$, 7 x 1976 (sterile), Dodson \& Gentry 6505 (MO, SEL); Río Palenque Biological Station, c. halfway between Quevedo and Santo Domingo de los Colorados, c. 200 m, 24 x 1974 (buds), Gentry 11998 (MO).

Hiraea cephalotes is easily separated from all other species discussed here, except $H$. angustipetala, by its adaxially sericeous sepals. The samaras are distinctive in that the dorsal wing has a large tooth at the point of insertion at the apex of the nut.

Cuatrecasas (1958) cited Sprague's (1924) assertion that Hiraea spruceana is a synonym of $H$. cephalotes, but could not confirm this assignment, because he did not see the type of $H$. spruceana.

\section{Hiraea ecuadorensis C.E.Anderson, sp. nov. Fig. 5.}

A Hiraea cephalote umbellis 30-40-floris, sepalis adaxaliter glabris et samaris sine ala dorsali differt. - Type: Ecuador, Morona-Santiago, oeste de la ciudad del Macas, bosque secundario, $02^{\circ} 18^{\prime} \mathrm{S}, 7^{\circ} 07^{\prime} \mathrm{W}, 1160$ m, 24 ii 1986 (fl, fr), Baker 6602 (holo MICH).

Woody vine. Leaves opposite; petioles $1.5-3 \mathrm{~cm}$ long, 2-3 mm wide, densely covered with sessile to subsessile hairs; stipules $1.5-2 \mathrm{~mm}$ long, borne in the basal 1/3 of petiole; laminas of the larger leaves $12.5-20.5 \times 8-12 \mathrm{~cm}$, elliptical, apex apiculate (or acuminate?), base cordate, adaxially with T-shaped hairs when young, soon glabrate to glabrous but some hairs retained on the costa, the hairs with a stalk to $0.1 \mathrm{~mm}$ long, trabecula $0.4-1 \mathrm{~mm}$ long, straight to wavy, abaxially woolly (in old leaves sparsely so and/or sloughed off), the dense vesture composed of T- and Y-shaped hairs, the hairs with a stalk $0.1-0.6 \mathrm{~mm}$ long, trabecula $0.6-1 \mathrm{~mm}$ long, wavy to curled, arms of Y-shaped hairs unequal, $0.1-0.4 \mathrm{~mm}$ long, wavy to curled and intertwined; adaxially veins slightly or not impressed; abaxially costa, secondary and tertiary veins prominent; leaf glands: margin with scattered glands $0.3-0.5 \mathrm{~mm}$ in diameter; with a pair of glands at the base of the lamina and also near the apex of the petiole, each gland c. $1 \mathrm{~mm}$ long. Inflorescence a solitary $30-40$-flowered umbel borne on an axis $3.5-8.5 \mathrm{~cm}$ long (in fruit), with a node at the middle to basal 1/4 (1 pair of reduced leaves seen: petiole c. $1 \mathrm{~mm}$, lamina c. $2 \times$ c. $2 \mathrm{~cm}$ ); umbel without a gland in the centre; bracts $0.8-1 \times$ c. $1 \mathrm{~mm}$, bracteoles like bracts or slightly shorter and/or narrower; pedicels 12-25 $\times$ c. $1.5 \mathrm{~mm}$; axes, abaxial surface of bracts and bracteoles, and pedicels densely sericeous. Sepals $1.2-1.5 \times$ c.1.5 mm wide, narrowly triangular, adaxially glabrous, abaxially sericeous; anterior sepal eglandular, the lateral four biglandular, glands $2.2-2.5 \mathrm{~mm}$ long. Petals yellow, glabrous; anterior-lateral petals with the claw c. $2.5 \mathrm{~mm}$ long, limb c. $7 \times$ c. $7 \mathrm{~mm}$, orbicular, margin subentire; posterior-lateral petals with the claw c. $2.5 \mathrm{~mm}$ long, limb c. $6.5 \times$ c. $6.5 \mathrm{~mm}$, orbicular, margin subentire proximally, the distal $1 / 4$ glandular-fimbriate, fimbriae to $0.7 \mathrm{~mm}$ long; posterior petal with the claw c. $3 \mathrm{~mm}$ long and thicker than that of lateral petals, limb 5-5.5 $\times 5-5.5 \mathrm{~mm}$, ovate, margin glandular-fimbriate, fimbriae to $0.8(-1) \mathrm{mm}$ long. Stamens glabrous, filaments basally connate; stamen opposite anterior sepal: filament $2.5 \mathrm{~mm}$ long, anther $1.8 \mathrm{~mm}$ long; 


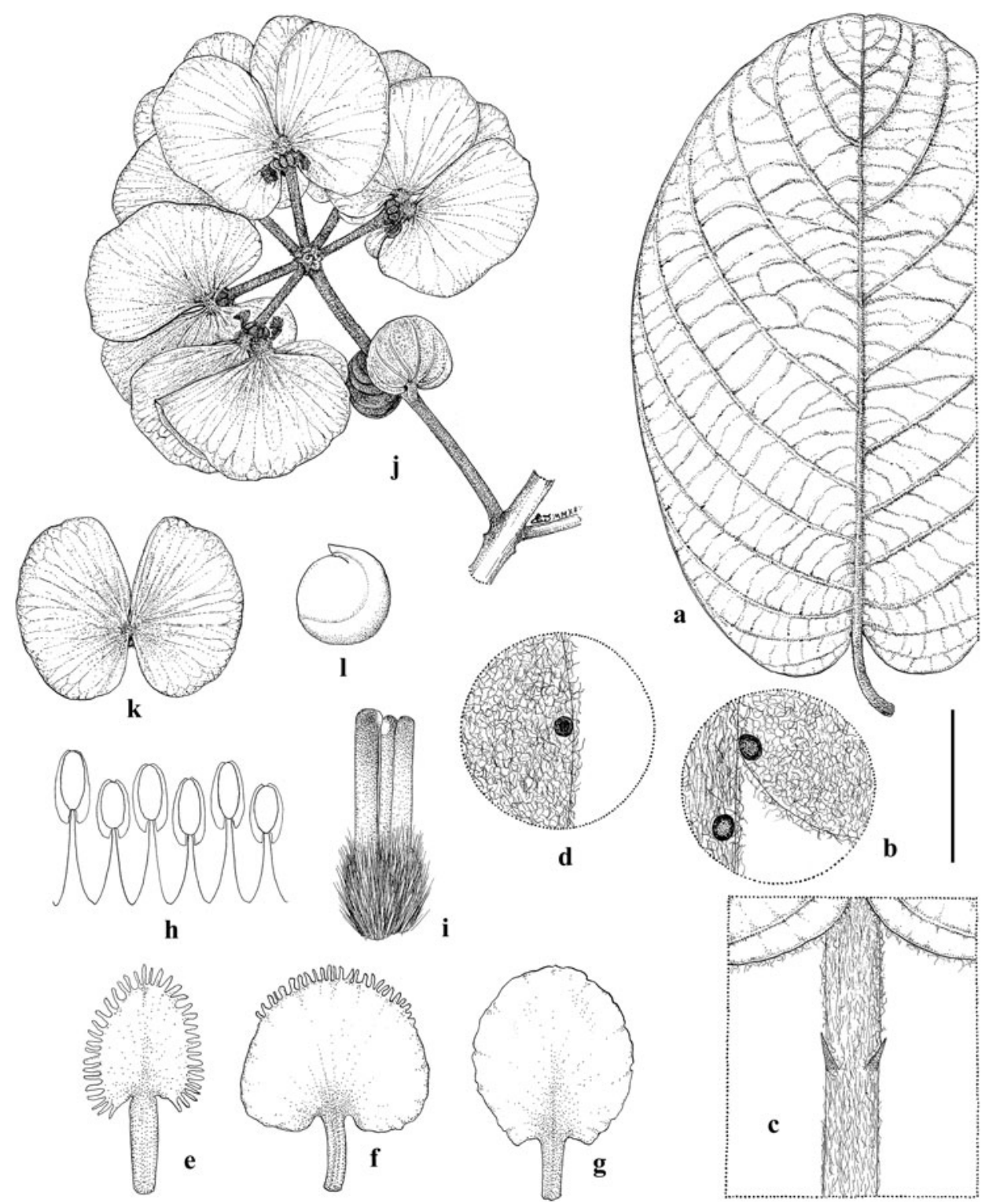

FIg. 5. Hiraea ecuadorensis C.E.Anderson. a, large leaf, abaxial view; $b$, glands near apex of petiole and at base of lamina, abaxial view; c, distal portion of petiole with a pair of stipules, adaxial view; d, marginal leaf gland, abaxial view; e, posterior petal; f, posterior-lateral petal; g, anterior-lateral petal; $h$, portion of androecium laid out, abaxial view, first stamen at right opposite posterior petal; i, gynoecium, anterior style at left; j, infructescence; $\mathrm{k}$, samara, abaxial view; 1, embryo. Scale bar equivalents: a, $4 \mathrm{~cm}$; b, $4 \mathrm{~mm}$; c, $8 \mathrm{~mm}$; d, $4 \mathrm{~mm}$; e-g, $5.7 \mathrm{~mm}$; h, 4 mm; i, 2.7 mm; j, k, 4 cm; 1, 8 mm. Based on: a-k, Baker 6602 (MICH); 1, Suin et al. $1292(\mathrm{MO})$. 
stamens opposite anterior-lateral petals: filaments $1.8-2 \mathrm{~mm}$ long, anthers $1.6-1.8 \mathrm{~mm}$ long; stamens opposite lateral sepals: filaments c. $2.2 \mathrm{~mm}$ long, anthers c. $1.8 \mathrm{~mm}$ long; stamen opposite posterior petal: filament c. $1.8 \mathrm{~mm}$ long, anther c. $1.5 \mathrm{~mm}$ long. Styles glabrous, erect, apex blunt, stigma on the internal angle of the apex; anterior style c. $2.5 \times$ c. $0.3 \mathrm{~mm}$; posterior styles c. $2.2 \times$ c. $0.3 \mathrm{~mm}$; ovary c. $1 \mathrm{~mm}$ long, densely villous. Samara butterfly-shaped; lateral wings $4.3-5.2 \times 3.1-3.5 \mathrm{~cm}$, dorsal wing absent; nut subspherical, 5.5-6 $\mathrm{mm}$ in diameter, areole c. $2 \mathrm{~mm}$ in diameter, circular; embryo subspherical, 5-5.3 mm in diameter, outer cotyledon c. $6.3 \times$ c. $4 \mathrm{~mm}$, folded at c. $1 / 2$ over the inner cotyledon, inner cotyledon c. $7 \times$ c. $3.8 \mathrm{~mm}$ wide, folded at c.1/3.

Distribution. Ecuador (Morona-Santiago).

Habitat. Secondary forest, remnant of primary forest; 1064-1160 m.

Additional specimen examined. EcuAdor. Morona-Santiago: Morona, Cordillera del Cucutú,

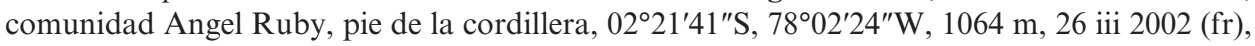
Suin et al. 1292 (MO).

Hiraea ecuadorensis is distinctive in that the samara bears large lateral wings but lacks a dorsal wing. The laminas of the type are densely woolly below, but in the second collection (Suin et al. 1292), also in fruit, the woolly abaxial vesture of the laminas is mostly sloughed off, and much of the abaxial surface is sparsely pubescent with patches of denser vesture on and near the major veins and the base. Of the other species treated here, only Hiraea mortoniana also has the limb of the posterior-lateral petals distally digitate-fimbriate.

\section{Hiraea escobariae C.E.Anderson, sp. nov. Fig. 6.}

A Hiraea cephalote stipulis longioribus, sepalis adaxaliter glabris et petalis minoribus differt. - Type: Colombia, Antioquia, Mpio. Guatapé, Vereda Santa Rita, bosque húmedo, c.1850 m, 27 ii 1986 (fl, fr), Albert de Escobar et al. 6331 (holo MICH).

Woody vine. Leaves opposite; petioles $0.5-1.5 \mathrm{~cm}$ long, c. $2 \mathrm{~mm}$ wide, densely velutinous; stipules $2.5-3.5 \mathrm{~mm}$ long, borne in the middle or basal $1 / 4$ of petiole; laminas 5-16 $\times$ $2.3-8 \mathrm{~cm}$, elliptical, apex apiculate, base acute or slightly cordate, adaxially velutinous and with some T-shaped hairs when young, glabrescent except for hairs retained on the veins, hairs sessile or with a stalk to $0.2 \mathrm{~mm}$ long, the arms mostly unequal and rudimentary to $0.2 \mathrm{~mm}$ long, abaxially with $\mathrm{T}$ - and $\mathrm{Y}$-shaped hairs, hairs with a stalk $0.2(-0.3) \mathrm{mm}$ long, the trabecula $0.3-1 \mathrm{~mm}$ long, wavy; adaxially veins impressed, abaxially costa, secondary and tertiary veins prominent; leaf glands: margin with scattered glands $0.2 \mathrm{~mm}$ in diameter; with a pair of glands at or near the base of the lamina abaxially or at the apex of the petiole, each gland c. $0.5 \mathrm{~mm}$ in diameter. Inflorescence a solitary (15-)17-25-flowered umbel borne on an axis 1.8-5 cm long, with a node bearing a pair of leafy bracts or reduced leaves (petiole to $2 \mathrm{~mm}$ long, lamina to $7 \mathrm{~mm}$ long, to $3 \mathrm{~mm}$ wide, elliptical) at distal $1 / 4-1 / 3$ or immediately below the umbel; umbel without a gland in the centre; bracts $1-1.2 \times 0.7-0.8 \mathrm{~mm}$, bracteoles 


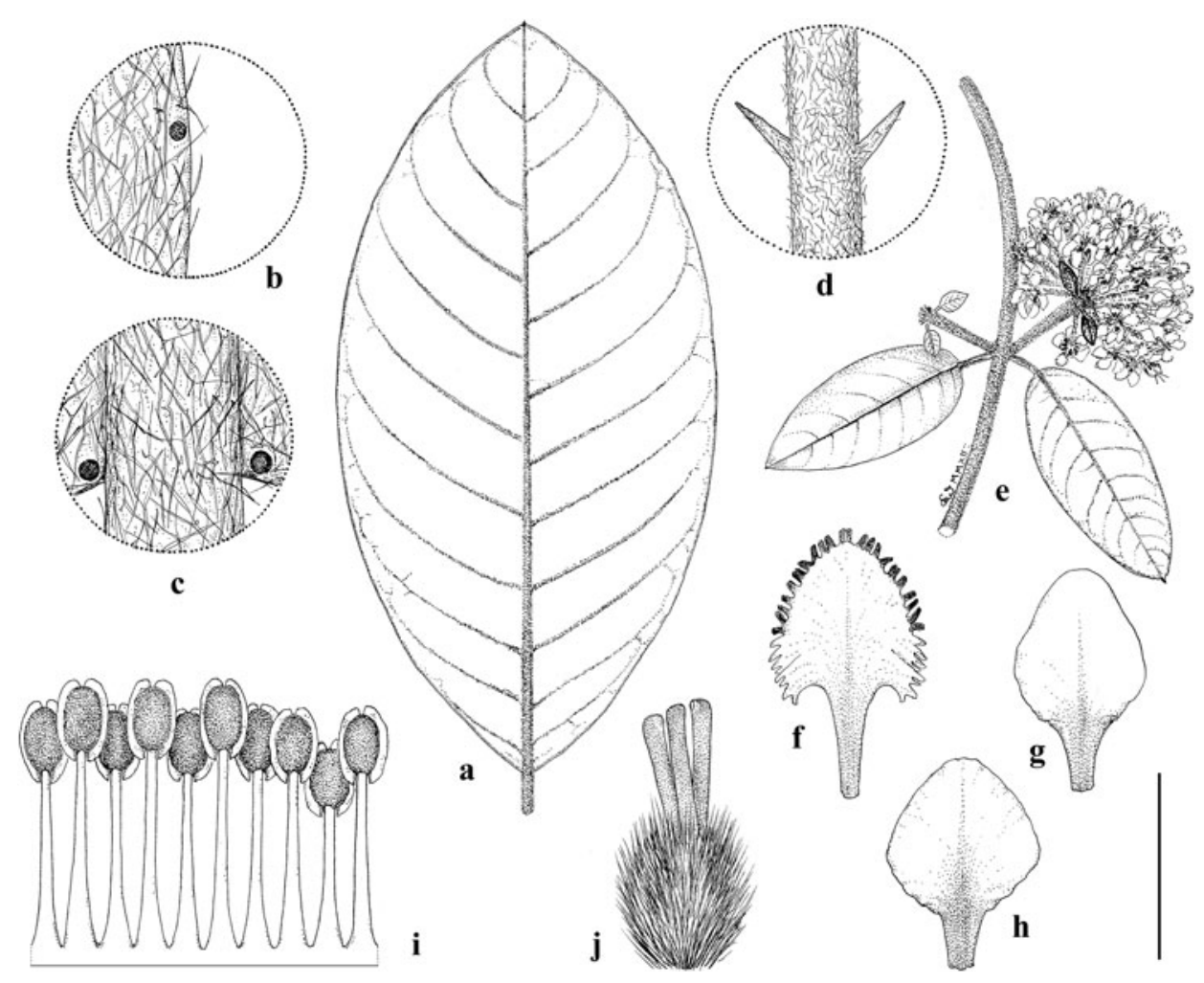

FIG. 6. Hiraea escobariae C.E.Anderson. a, large leaf, abaxial view; b, marginal leaf gland, abaxial view; c, glands at base of lamina, abaxial view; d, portion of petiole with a pair of stipules, adaxial view; e, portion of stem with inflorescence; f, posterior petal; $g$, posterior-lateral petal; $\mathrm{h}$, anterior-lateral petal; i, androecium laid out, abaxial view, second stamen from right opposite posterior petal; j, gynoecium, anterior style at left. Scale bar equivalents: a, $4 \mathrm{~cm}$; b, c, $2 \mathrm{~mm}$; d, $8 \mathrm{~mm}$; e, $4 \mathrm{~cm}$; f-h, 4 mm; i, j, $2.7 \mathrm{~mm}$. Based on: a, Fonnegra G. et al. 4725 (MICH); b-j, Albert de Escobar et al. $6331(\mathrm{MICH})$.

like bracts or slightly shorter and/or narrower; pedicels $15-22 \times 0.5 \mathrm{~mm}$; axes, abaxial surface of bracts and bracteoles, and pedicels densely covered with T-shaped hairs. Sepals $1.5-1.7 \times 1.3-1.5 \mathrm{~mm}$, triangular, adaxially glabrous, abaxially with subsessile T-shaped hairs; anterior sepal eglandular, the lateral four biglandular, glands 1.8 $2.2 \mathrm{~mm}$ long, prominent. Petals yellow to orange, tinged with red, glabrous; lateral petals with the claw 1-1.5 mm long, limb 3-3.5 $\times 3-3.5 \mathrm{~mm}$, (sub)orbicular, margin subentire; posterior petal with the claw $2.5-2.6 \mathrm{~mm}$ long and thicker than that of lateral petals, decurrent, limb 3.5-3.6 $\times 3-3.5 \mathrm{~mm}$, broadly triangular, margin proximally denticulate/fimbriate, the distal $3 / 4$ digitate-fimbriate, the fimbriae to $0.6(-0.8) \mathrm{mm}$ long. Stamens glabrous, filaments basally connate; stamen opposite anterior sepal: filament $2.7-2.8 \mathrm{~mm}$ long, anther c. $1.2 \mathrm{~mm}$ long; stamens opposite anterior-lateral petals: filaments $2.3-2.4 \mathrm{~mm}$ long, anthers c. $1 \mathrm{~mm}$ long; stamens 
opposite anterior-lateral sepals: filaments c. $2.5 \mathrm{~mm}$ long, anthers c. $1.2 \mathrm{~mm}$ long; stamens opposite posterior-lateral petals: filaments c.2.1-2.3 mm long, anthers c. $1 \mathrm{~mm}$ long; stamens opposite posterior-lateral sepals: filaments $2.4-2.5 \mathrm{~mm}$ long, anthers c. $1 \mathrm{~mm}$ long; stamen opposite posterior petal: filament 2-2.1 mm long, anther c. $1 \mathrm{~mm}$ long. Styles glabrous, erect, apex blunt, stigma on the internal angle of the apex; anterior style c. $1.8 \times$ c. $0.3 \mathrm{~mm}$; posterior styles c. $2 \times$ c. $0.3 \mathrm{~mm}$; ovary $1.3-1.5 \mathrm{~mm}$ long, densely villous. Mature samara not seen; immature samara butterfly-shaped, dorsal wing present.

Distribution. Colombia (Antioquia, Cundinamarca).

Habitat. Wet forest; 1100-1850 m.

Etymology. This species is named for Linda Katherine Albert de Escobar (1940-1993), student of Passiflora and of the Colombian flora, who first collected it.

Additional specimens examined. Colombia. Antioquia: Mpio. Amalfi, Vereda Arenasblancas, $06^{\circ} 55^{\prime} \mathrm{N}, 74^{\circ} 55^{\prime} \mathrm{W}, 1100-1250 \mathrm{~m}, 11$ iv 1994 (buds), Fonnegra G. et al. 4725 (MICH). Cundinamarca: Mpio. Yacopí, Insp. de Policía de Guadalito, Vereda de La Laguna, 1245-1600 m, 28 x 1995 (buds), Lozano et al. 7214 (COL).

Hiraea escobariae differs from $H$. cephalotes by its smaller flowers with adaxially glabrous sepals and borne on longer slender pedicels. The major veins are impressed in the adaxial surface of the leaf blade, and the stipules measure 2.5-3.5 mm long. In its velutinous, elliptical leaves and small flowers, Hiraea escobariae resembles H. angustipetala, which differs in its adaxially sericeous sepals, narrow petals, minute caducous stipules (to $1 \mathrm{~mm}$ long), and terminal stigmas. Hiraea escobariae is known from only three fragmentary specimens, of which two are in bud. The fruit on the type specimen is very young, but a dorsal wing is clearly present on the developing samaras.

Hiraea mortoniana (J.F.Macbr.) C.E.Anderson, comb. et stat. nov. - Hiraea spruceana var. mortoniana J.F.Macbr., Field Mus. Publ. Bot. 13(3): 797 (1950). - Type: Peru, San Martín, Zepelacio, near Moyobamba, 1100-1200 m, x-xi 1933, Klug 3332 (holo F; iso A, GH, MO, NY, US, WIS). Fig. 7.

Woody vine. Leaves opposite; petioles $3.5-6.5 \mathrm{~cm}$ long, 2-3.5 mm wide, densely sericeous but glabrescent with age; stipules $1.5-3 \mathrm{~mm}$ long, borne at or slightly below middle of petiole; laminas $20-30 \times 10.5-20.5 \mathrm{~cm}$, elliptical to ovate, apex apiculate, base slightly cordate, adaxially glabrate but some $\mathrm{T}$-shaped hairs retained on the costa, abaxially sparsely pubescent with T-shaped hairs to glabrate and eventually glabrous, the hairs sessile to subsessile or with a stalk $0.1-0.2 \mathrm{~mm}$ long, trabecula 0.4-1.5 mm long, straight to wavy; adaxially veins not impressed; abaxially costa, secondary and tertiary veins prominent; leaf glands: margin with scattered glands c. $0.3 \mathrm{~mm}$ in diameter; with a pair of glands at the base of the lamina, each gland $0.5-1 \mathrm{~mm}$ long (sometimes with an additional smaller gland c. $0.5 \mathrm{~mm}$ long), and with a pair of glands on the petiole up to $6 \mathrm{~mm}$ below the lamina base, each gland 1-2 $\mathrm{mm}$ long. 


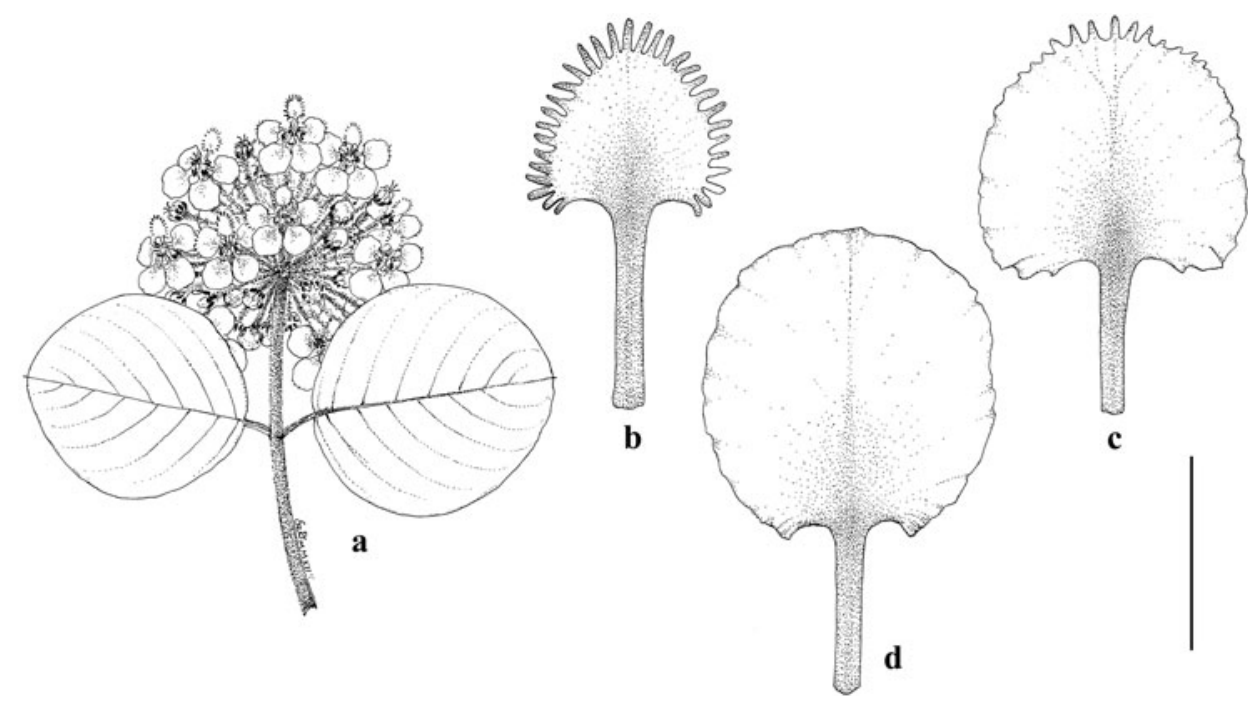

FIG. 7. Hiraea mortoniana (J.F.Macbr.) C.E.Anderson. a, inflorescence; b, posterior petal; c, posterior-lateral petal; d, anterior-lateral petal. Scale bar equivalents: a, $4 \mathrm{~cm}$; b-d, $4 \mathrm{~mm}$. Based on Klug 3332 (A).

Inflorescence a solitary 20-35-flowered umbel borne on an axis $6.5-8.2 \mathrm{~cm}$ long, with a node bearing a pair of reduced leaves at the middle or distal 1/3-1/4 (petiole 2-6.3 mm long, lamina $2-6 \times 2-5 \mathrm{~cm}$, broadly elliptical to orbicular); umbel without a gland in the centre; bracts $1-1.2 \times \mathrm{c} .1 \mathrm{~mm}$, bracteoles like bracts or slightly shorter and/or narrower; pedicels $18-25 \times \mathrm{c} .1 \mathrm{~mm}$; axes, abaxial surface of bracts and bracteoles, and pedicels densely sericeous. Sepals c. $1.5 \times$ c. $2 \mathrm{~mm}$, triangular, adaxially glabrous, abaxially sericeous; anterior sepal eglandular, the lateral four biglandular, or sometimes all biglandular, glands $1.6-2 \mathrm{~mm}$ long, prominent. Petals yellow, glabrous; anterior-lateral petals with the claw 3-3.5 mm long, limb 6-7 × 6-7 mm, orbicular, margin subentire; posterior-lateral petals with the claw c. $2.5 \mathrm{~mm}$ long, limb 5-6 $\times$ 5-6 mm, orbicular, margin proximally subentire and/or denticulate, the distal 1/4-1/2 digitate-fimbriate, the fimbriae to $0.5 \mathrm{~mm}$ long; posterior petal with the claw $3.5-4 \mathrm{~mm}$ long and thicker than that of lateral petals, limb 3.5-4.5 $\times 3.5-4.5 \mathrm{~mm}$, orbicular, margin digitate-fimbriate, fimbriae to $1 \mathrm{~mm}$ long. Stamens glabrous, filaments basally connate; stamen opposite anterior sepal: filament c. $3 \mathrm{~mm}$ long, anther $1.5-1.6 \mathrm{~mm}$ long; stamens opposite anterior-lateral petals: filaments c. $2.5 \mathrm{~mm}$ long, anthers c. $1.2 \mathrm{~mm}$ long; stamens opposite anterior-lateral sepals: filaments c. $3 \mathrm{~mm}$ long, anthers c. $1.5 \mathrm{~mm}$ long; stamens opposite posterior-lateral petals: filaments $2.1-2.3 \mathrm{~mm}$ long, anthers c. $1.3 \mathrm{~mm}$ long; stamens opposite posterior-lateral sepals: filaments $2.5-2.6 \mathrm{~mm}$ long, anthers 1.1-1.2 mm long; stamen opposite posterior petal: filament c. $2 \mathrm{~mm}$ long, anther c. $1.1 \mathrm{~mm}$ long. Styles glabrous, erect, apex blunt, stigma on the internal angle of the apex; anterior style $1.8-2 \times 0.3 \mathrm{~mm}$; posterior styles $2-2.3 \times 0.2-0.3 \mathrm{~mm}$; ovary $1.7-1.8 \mathrm{~mm}$ long, densely villous. Samara not seen. 
Hiraea mortoniana is known only from the type collection, which Macbride (1950) recognised as a variety of $H$. spruceana [ $H$. cephalotes], although he noted his uncertainty about this assignment. It differs from Hiraea cephalotes in its nearly glabrous laminas and adaxially glabrous sepals; the abaxial vesture is sparse even in the reduced leaves on the inflorescence axes. The stipules are inserted at the middle of the petiole, not in the basal 1/4, as in Hiraea cephalotes, and the limb of the posterior-lateral petals is apically digitate-fimbriate instead of subentire. In the species of Hiraea with multiflowered umbels the inflorescence axis bears one node with a pair of leafy bracts or greatly reduced leaves; however, in $H$. mortoniana these leaves have the lamina 2-6× $2-5 \mathrm{~cm}$ and orbicular or nearly so, and much exceed the largest seen in $H$. cephalotes (lamina up to $12 \times 8 \mathrm{~mm}$, elliptical) and the other species discussed here. The one pair of reduced leaves seen on an inflorescence axis of Hiraea ecuadorensis has the lamina c. $2 \times$ c. $2 \mathrm{~cm}$, but the abaxial surface is densely woolly.

\section{Hiraea peruviana C.E.Anderson, sp. nov. Fig. 8.}

A Hiraea cephalote foliis ellipticis velutinis, sepalis adaxaliter glabris et petalo postico margine proximaliter subintegro distaliter irregulariter denticulato differt. - Type: Peru, Pasco, Oxapampa, Dtto. Huancabamba, localidad Grapanazu, sector San Daniel, inmediaciones de los Fundos ganaderos y de cultivos, bosque secondario, 10²6'53"S, 75²7'04"W, 2094 m, 14 vii 2004 (fl), Perea et al. 1637 (holo MICH).

Woody vine. Leaves opposite; petioles $1-2.5 \mathrm{~cm}$ long, $1.5-2 \mathrm{~mm}$ wide, densely velutinous; stipules 1.5-3 mm long, borne in the middle to basal 1/4 of petiole; laminas of the larger leaves $8-13.5 \times 2.5-5.3 \mathrm{~cm}$, lanceolate to narrowly elliptical or narrowly ovate, apex acuminate to long-acuminate, base acute to truncate, adaxially velutinous, the hairs Y-shaped, with a stalk $0.1-0.3 \mathrm{~mm}$ long, the arms mostly unequal, rudimentary to $0.3 \mathrm{~mm}$ long, abaxially with a mixture of $\mathrm{Y}$ - and T-shaped hairs, the T-shaped hairs with a stalk $0.2-0.3 \mathrm{~mm}$ long, the trabecula $0.3-0.5 \mathrm{~mm}$ long, straight to wavy or crisped; adaxially veins not impressed; abaxially costa, secondary and tertiary veins prominent; leaf glands: margin with scattered glands c. $0.2 \mathrm{~mm}$ in diameter; with a pair of glands borne abaxially at the base or near the base of the lamina or at the apex of the petiole, each gland 0.3-0.6 $\mathrm{mm}$ long. Inflorescence a solitary 20-25-flowered umbel borne on an axis 3-3.5 cm long, with a node bearing deciduous leafy bracts at the middle or distal 1/3-1/4; umbel without a gland in the centre; bracts $0.5-1 \times 0.5-1 \mathrm{~mm}$, bracteoles like bracts or slightly shorter and/or narrower; pedicels 13-19.5 × 1-1.5 mm; axes, abaxial surface of bracts and bracteoles, and pedicels densely sericeous. Sepals $1.8-2 \times 1.8-2 \mathrm{~mm}$, triangular, adaxially glabrous, abaxially densely sericeous; anterior sepal eglandular, the lateral four biglandular, glands c. $2 \mathrm{~mm}$ long, prominent. Petals yellow to orange, glabrous; lateral petals with the claw c. $1.5 \mathrm{~mm}$ long, limb 3-4 $\times 3-4 \mathrm{~mm}$, broadly elliptical, margin subentire; posterior petal with the claw c. $1.5 \mathrm{~mm}$ long and thicker than that of lateral petals, limb c. $3.5 \times$ c. $3.5 \mathrm{~mm}$, broadly elliptical to suborbicular, margin subentire near base to irregularly denticulate distally. Stamens glabrous, filaments basally connate; stamen opposite 


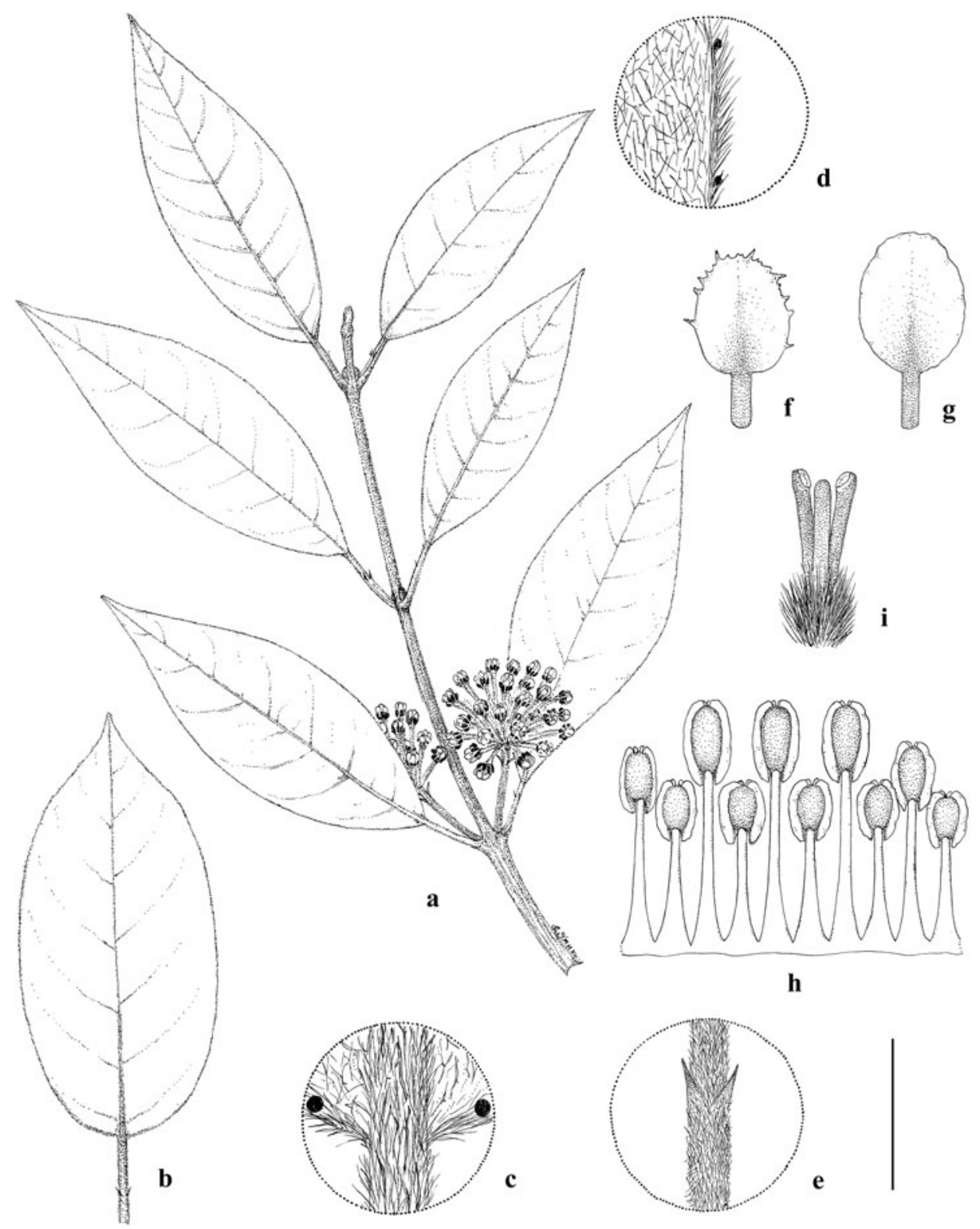

Fig. 8. Hiraea peruviana C.E.Anderson. a, flowering branch; b, large leaf, adaxial view; c, base of lamina with a pair of glands, abaxial view; d, detail of lamina, abaxial view, showing marginal glands; e, portion of petiole with a pair of stipules, adaxial view; f, posterior petal; $\mathrm{g}$, lateral petal; $\mathrm{h}$, androecium laid out, abaxial view, the stamen first from right opposite posterior petal; i, gynoecium, anterior style in the centre. Scale bar equivalents: a, b, $4 \mathrm{~cm}$; c, d, $4 \mathrm{~mm}$; e, $8 \mathrm{~mm}$; f, g, $4 \mathrm{~mm}$; h, i, $2.7 \mathrm{~mm}$. Based on: a, Valenzuela et al. 11778 (MICH); b-e, Smith et al. 8714A (MO); f-i, Perea et al. 1637 (MICH). 
anterior sepal: filament c. $2.5 \mathrm{~mm}$ long, anther c. $1.5 \mathrm{~mm}$ long; stamens opposite anterior-lateral petals: filaments c. $2 \mathrm{~mm}$ long, anthers c. $1.1 \mathrm{~mm}$ long; stamens opposite anterior-lateral sepals: filaments c. $2.5 \mathrm{~mm}$ long, anthers c. $1.5 \mathrm{~mm}$ long; stamens opposite posterior-lateral petals: filaments c. $1.8 \mathrm{~mm}$ long, anthers c. $1.1 \mathrm{~mm}$ long; stamens opposite posterior-lateral sepals: filaments c. $2.4 \mathrm{~mm}$ long, anthers c. $1.2 \mathrm{~mm}$ long; stamen opposite posterior petal: filament c. $1.8 \mathrm{~mm}$ long, anther c. $1 \mathrm{~mm}$ long. Styles glabrous, erect, apex blunt, stigma on the internal angle of the apex; anterior style c. $1.8 \times$ c. $0.3 \mathrm{~mm}$; posterior styles c. $2 \times$ c. $0.2 \mathrm{~mm}$; ovary c. $1.8 \mathrm{~mm}$ long, densely villous. Samara not seen.

Distribution. Peru (Pasco).

Habitat. Primary and secondary montane forest; 1900-2300 m.

Additional specimens examined. Peru. Pasco: Prov. Oxapampa, Palmazú, $10^{\circ} 32^{\prime} \mathrm{S}, 75^{\circ} 23^{\prime} \mathrm{W}$, 1900-2300 m, 5 x 1984 (fl), Smith et al. 8714A (MO); Oxapampa, Dtto. Huancabamba, Parque Nacional Yanachaga-Chemillén, La Colmena, 10²6'56"S, 75²6'26"'W, 2238 m, 27 viii 2008 (fl), Valenzuela et al. 11778 (MICH).

Hiraea peruviana is distinctive in its velutinous, lanceolate to narrowly ovate laminas. It differs from Hiraea cephalotes also in its adaxially glabrous sepals and is easily separated from all the species discussed here by the posterior petal, which lacks fimbriae; the margin is subentire toward the base and distally irregularly denticulate.

\section{ACKNOWLEDGEMENTS}

I thank W. R. Anderson for his comments and suggestions. The curators of the following herbaria kindly provided access to their collections: A, AAU, BM, CGE, COL, F, GH, INPA, K, MER, MG, MICH, MO, NY, P, SEL, US, WAG and WIS. Karin Douthit drew the handsome illustrations. This study was supported in part by a grant from the National Science Foundation to the University of Michigan (DEB-0543909).

\section{REFERENCES}

Cuatrecasas, J. (1958). Prima Flora Colombiana. Malpighiaceae. Webbia 13: 343-664.

Dugand, A. (1944). Itinerarios botánicos de José Jerónimo Triana. Revista Acad. Colomb. Ci. Exact. 5(20): 483-489.

Jussieu, Adr. De (1843). Monographie de la famille des Malpighiacées. Arch. Mus. Hist. Nat. 3: 5-151, 255-616, pl. 1-23.

Macbride, J. F. (1950). Hiraea. In: 'Flora of Peru', Field Mus. Nat. Hist., Bot. Ser., 13(3:3): 793-799.

Niedenzu, F. (1906). De genere Hiraea. Verzeichnis Vorles. Königl. Lyceum Hosianum Braunsberg Winter-Semester 1906/7: 1-17.

Niedenzu, F. (1912). Malpighiaceae americanae I. Arbeiten Bot. Inst. Königl. Lyceums Hosianum Braunsberg IV: 1-34.

Niedenzu, F. (1928). Hiraea. In: Engler, A. (ed.) Das Pflanzenreich, IV. 141, pars 1(Heft 91): 125-149. Leipzig: Wilhelm Engelmann. 
Sprague, T. A. (1924). Hiraea quapara. J. Bot. 62: 21-22.

Triana, J. J. \& Planchon, J. E. (1862). Hiraea. In: 'Prodromus florae Novogranatensis', Ann. Sci. Nat., Bot., sér. 4, 18: 326-332.

Received 29 May 2012; accepted for publication 6 February 2013 